\title{
APPLICATION OF BUILDING INTEGRATED PHOTOVOLTAIC ELECTRIC SYSTEM: ITS CONTRIBUTION IN REDUCTION OF LOAD SHEDDING HOURS IN NEPAL
}

\author{
Er. Jagan Nath Shrestha, Ph.D. \\ Director, Center for Energy Studies, Institute of Engineering, Tribhuvan University \\ E-mail: shresthajn@gmail.com
}

\begin{abstract}
Nepal, with a per capita energy consumption of about $15 \mathrm{GJ}$, is one of the five least energy consuming countries in the world. About $85 \%$ of its total energy comes from traditional energy sources such as fuel wood, agriculture residues and animal waste. This has led to grave consequences on ecological and environmental degradation. Keeping this in mind, GoN has provided policy guidelines in its Three Year Interim Plan (2007/08-10/11) to encourage the development and application of Renewable Energy Technologies such as photovoltaic power systems. This paper contains a brief account of the survey of PV powered solar home, telecommunication, civil aviation and water pumping systems in different parts of Nepal. As of July 15, 2008, about $6 \mathrm{MWp}$ of PV power has been already installed in 67 districts of Nepal. The paper indicates on how load shedding hours could be reduced to some extent if Building Integrated Photovolatic Electric System (BIPVES) is introduced in different major cities of Nepal. The paper concludes that BIPVES systems be installed and awareness programmes on application of these systems are needed for different levels of people so that the quality of life could be improved.
\end{abstract}

Key words: energy resources, building integration, urban renewable energy policy

\section{NATURAL ENERGY RESOURCES OF NEPAL}

Nepal is one of the richest countries in hydropower resources. About 6,000 rivers with a total length of about $45,000 \mathrm{~km}$ with an annual discharge of 174 billion cubic meters of water are available in the country [1]. The theoretical and commercial potential of hydro-power in Nepal are said to be about 83,000 MW and 42,000 MW respectively. So far only 617 MW have been connected to peak load system, which constitute about $2 \%$ of total energy supply [2]. Forests supply nearly $78 \%$ of the total energy requirement of the country, and also provide $50 \%$ of fodder for livestock purpose. No proven significant deposits of fossil fuel are available.

On average Nepal has 6.8 sunshine hours per day, i.e. 2,482 sunshine hours per year with the intensity of solar insolation ranging from 3.9 to $5.1 \mathrm{kWh} / \mathrm{m}^{2} /$ day (National average is about $4.7 \mathrm{kWh} / \mathrm{m}^{2} /$ day.) [3]. Though significant wind potential is noted to be available in mountainous region (Mustang district, Khumbu region, Palpa, Ramechhap, Karnali Chisapani, Jumla) no proper wind mapping of Nepal has been prepared so far.

\section{PRESENT ENERGY CONSUMPTION SCENARIO}

Nepal relies to a large extent on the traditional energy resources, as no proven significant deposit of fossil fuel is available. Based on the studies, the total energy consumption in Nepal was 7.159 million TOE in 2006/07 and it is expected to reach to 9.814 million TOE (about 15 GJ per capita) in the year 2007/08 [4]. Traditional energy occupied $85 \%$, commercial energy occupied about $13.90 \%$ and renewable/others occupied only $0.6 \%$ of the total estimated energy consumption in 2007/08 [4]. 
The composition of the petroleum products and coal has increased from $6 \%$ to $11 \%$ in the last 14 years mostly due to the increase of the demand in transportation sector and industrial sector. At the same period the consumption of the petrol has increased by $131 \%$ and coal by $161 \%$. This increment has resulted the draining out of the hard earned foreign currency and at the same time created the environmental pollution.

The Peak load demand measured on December 31, 2007 at 1815 hours was 721.73 MW. The energy demand reached $3490 \mathrm{GWh}$ as against available $3180 \mathrm{GWh}$. Due to this deficit the load shedding was carried out to keep the electricity supply running.

The total supplied energy consists of $86.75 \%$ from hydro source, which includes $30.2 \%$ from the independent power producers, $12.97 \%$ from imports and the remaining from thermal plants.

The peak load demand in wet season (8 August 2007) at 1915 hours was measured to be 643.5 MW with a deficit of about 120 MW. The load shedding is being introduced even during day time.

Nepal in contrary of being one of the richest countries in the world in hydro resources, it is now facing a severe challenge of load shedding. Though load shedding is not new for the country during dry season, to one's dismay, the country so far has had faced 42 hours load shedding per week in the worst case. Nepal Electricity Authority is estimating 12 hours a day power outage if the current situation does not improve at all. Estimating the country's potential of hydro electricity as $83,000 \mathrm{MW}$, Nepal has been dreaming of exporting electricity to neighbouring countries for the last 50 years. In 1911 A.D., the first hydropower station (Pharping Hydropower, 500kW) was installed in Nepal. At that time the only hydro-power station was in Darjeeling and no hydro-power station in China. As per Human Development Report 2007/08, in year 2004, per capita electricity consumption in India and China has reached to $618 \mathrm{kWh}$ and 1,684 $\mathrm{kWh}$ respectively. Per capita electricity consumption is only $86 \mathrm{kWh}$ in Nepal. This simply shows how the hydropower development is taking place in Nepal for the past several decades.

Nepal has had 60 ministers responsible for hydro-power development after 1951 A.D. But the pace at which the development of hydropower is taking place simply leaves no space to get relief from load shedding immediately. Now time has come to think about managing the domestic load instead of heavily relying and waiting for future hydropower development. Thus, in order to reduce power outage, in the current situation, the Building Integrated Photovoltaic Electric System (BIPVES) need to be discussed and introduced.

\section{BIPVES PROGRAMME IN NEPAL}
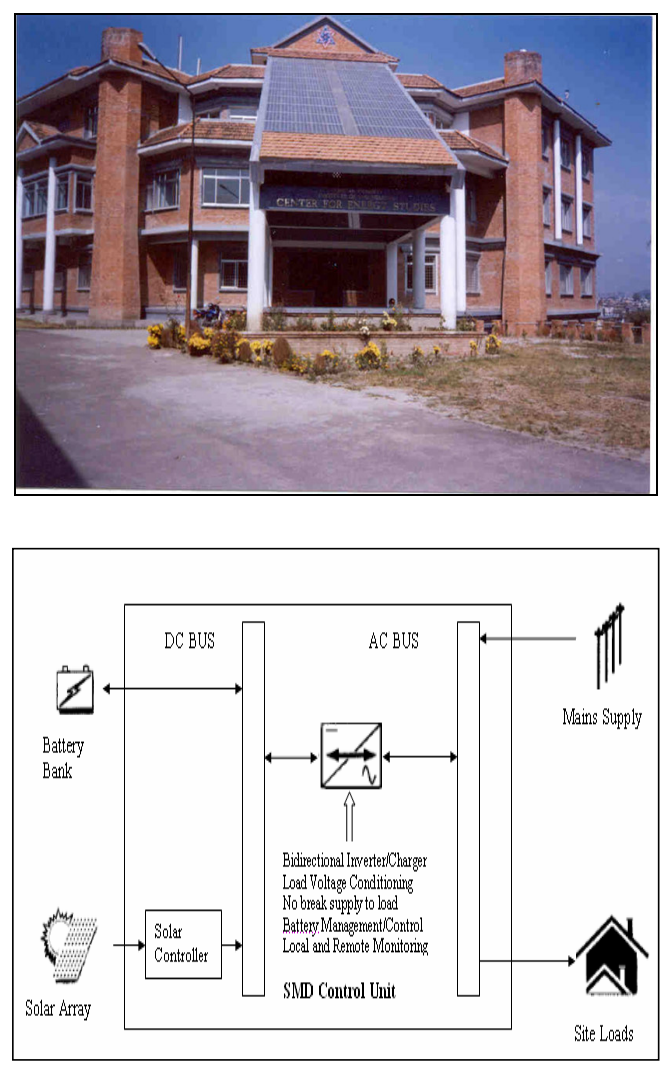

The first BIPVES installed at Center for 
Energy Studies in Nepal with following specification is shown above:

Volta Solar PV Tubular Plate Battery, Model \# DC 3255/6 (2V 468 AH@10 HR), \# of battery used: $240(120$ x 2 VDC - 120x 2VDC parallel), $100 \mathrm{PV}$ modules each with No. of cells 36, Rated Power: $65 \mathrm{Wp}$, Open circuit Voltage : $20.5 \mathrm{~V}$, Shirt Circuit : $4.7 \mathrm{~A}$ Max. Power Voltage: 16.3 V, Max. Power current: 4 A, Cell type: Mono, Max. System $\mathrm{V}_{\mathrm{OC}}: 600 \mathrm{~V}$. This system is generating about $27 \mathrm{kWh}$ per day but is not connected to grid as there is no policy for doing so.

BIPVES programmes could be integrated to local grid as in many developing countries like USA,

Japan, Germany etc. More than $85 \%$ of total PV power of about $29000 \mathrm{MW}$ in 2007 in the World has been used for grid connection, BIPVES based energy generations should be promoted and provision should be made to sell back the energy generated during the day time to national utility grid.

As well said, prevention is better than cure. BIPVES related research and development, analysis, policy studies are required to be conducted in Nepalese Universities. These studies will help in formulating the national strategy on BIPVES development.

\section{POLICY ANALYSIS}

Government of Nepal has the sole responsibility for establishing the statutory, legal and policy framework for the energy sector. The statutory framework, under which public and private energy supply activities take place, is included in a number of Acts and Regulations approved by the parliament.

The current Three Year Interim Plan (2007/08 - 2010/11 envisaged to supply electricity to $60 \%$ of urban people through national grid. The plan emphasized: (1) increasing the consuming capacity of urban families by developing and extending the availability of energy sources; (2) reducing dependency on imported energy sources, and reducing negative environmental effects by the proper use of resources and tools of local energy and (3) by improving and increasing the energy use competency and increasing the access of rural people by reducing the cost of development and installation of alternative sources of energy.

\section{SUBSIDY POLICY}

Government of Nepal has published subsidy policy covering subsidy for stand-alone PV systems, micro-hydro systems, solar dryers and cookers, wind energy generation. The Government of Nepal has recently decided (March 2008) to exempt tax and VAT on imported PV modules to be used in urban areas to adjust load shedding hours in urban areas.

To accelerate this action, Government of Nepal has recently (April 2009) decided to provide a subsidy of Rs. 10,000 to the owners of each household in urban areas wishing to install $20 \mathrm{Wp}$ or more photovoltaic based Solar Home Systems. This will have a tremendous impact on future BIPVES development programme in Nepal.

\section{SOLAR PHOTOVOLTAIC TECHNOLOGY}

The country has 300 sunny days per annum and thus is very rich in solar power potential. Using PV module of $12 \%$ efficiency, total energy generated will be $0.12 * 4.5 *$ $147,181 * 10^{\wedge} 6=80,000 \mathrm{GWh} /$ day $=17.7 \mathrm{TW}$ (assuming peak sun to be 4.5 hours)

This energy generated is more than energy required for fulfilling the whole energy demand of the world.

The total estimated world energy demand at present is about $13 \mathrm{TW}$. If we use just $0.01 \%$ of the total area of Nepal, we can generate solar electricity of $8 \mathrm{GWh} /$ day, that is 2920 $\mathrm{GWh} /$ year (which is more than the energy generated by NEA in the year 2003 
amounting $2261 \mathrm{GWh} /$ year)

\subsection{Major Users of Solar Electricity in Nepal}

First officially recorded use of solar electricity in Nepal is not known. But it is said that the then Nepal Telecommunications Corporation (NTC) was the first organization to use solar electricity to power a high frequency communication transceiver located in Damauli in 1974. Since then NTC has become one of the significant users of solar electricity amounting to more than $1000 \mathrm{kWp}$ generating about $47000 \mathrm{kWh} /$ day of electrical energy at more than 3000 locations, without national grid supplied electricity. Seventy five percent of all the Public Call Offices (PCO) in NTC are being powered by PV.

The estimated market potential is huge and about $4,636 \mathrm{kWp}$ of photovoltaic power is currently being used in various public and private sectors (telecommunication, utility supply, stand-alone, water supply, aviation etc.) in Nepal are shown in Table 1 [3].

Table 1: Application of PV Power by Sector

\begin{tabular}{|c|l|l|l|l|}
\hline S.N. & Service & $\begin{array}{l}\text { PV } \\
\text { Power, } \\
\mathrm{kWp}\end{array}$ & $\begin{array}{l}\% \\
\text { Powe } \\
\mathrm{r}\end{array}$ & $\begin{array}{l}\text { No. of } \\
\text { Installation }\end{array}$ \\
\hline 1 & $\begin{array}{l}\text { Telecommu } \\
\text { nications }\end{array}$ & 1001 & 21.6 & $3,000+$ \\
\hline 2 & $\begin{array}{l}\text { Utility } \\
\text { supply } \\
\text { (centralised } \\
\text { ) }\end{array}$ & 100 & 2.1 & 2 \\
\hline 3 & $\begin{array}{l}\text { Stand-alone } \\
\text { system }\end{array}$ & 3328 & 71.8 & $75,000+$ \\
\hline 4 & $\begin{array}{l}\text { Water } \\
\text { supply }\end{array}$ & 93 & 2.0 & 25 \\
\hline 5 & Aviation & 37 & 0.8 & 45 \\
\hline 6 & $\begin{array}{l}\text { Miscellane } \\
\text { ous }\end{array}$ & 78 & 1.7 & $100+$ \\
\hline & Total & $\begin{array}{l}4,636 \\
(6000 \\
\text { kWp as } \\
\text { of 15 } \\
\text { July } \\
2008 / S E \\
\text { MAN) }\end{array}$ & 100 & \\
\hline
\end{tabular}

Stand-alone Solar Home System (SHS) constitute above $3328 \mathrm{kWp}$ with 90,172 numbers [1] as of December, 2005.

In near future more and more PV systems will be used for various types of services. There is a plan to install 52000 solar home systems in areas where national grid will not reach within the current three year interim plan. These facts indicate that time has come to pay special attention for PV powered systems for income generating activities.

\section{PROBLEMS IN DEVELOPMENT OF BIPVES}

The problems in developing, promoting and disseminating BIPVES seem to be (i) high initial capital cost; (ii) inefficient financial institutional base; (iii) lack of awareness among urban people, (iv) insufficient applied research and development.

\section{CONCLUSIONS}

Nepal has been endowed with vast natural energy resources but their fruitful utilization for the well being of her ever growing population has not been satisfactory due to the economic, geographical, technical and political reasons. Majority of the population relies on the traditional biomass and expensive imported fossil fuels for fulfilling their energy needs. The inefficient use of biomass and increasing use of fossil fuels have contributed to the indoor as well as the outdoor environment degradation.

The alternative energy supply options consisting of renewable energy technologies and efficient energy technologies have been proved as the clean form of energy applications in order to save the local and global environment. So there is the urgent need to promote affordable and acceptable renewable energy technologies in the country for preserving the local environment, natural resources and control the Global Climate Change induced calamities. There should be a continuous effort to take benefit by implementing renewable energy projects based on Clean Development Mechanism. 
The recommendations for different stake holders and their role for the promotion of BIPVES are:

- The financial institution should play an active role in urban areas by financing technically sound and environment-friendly BIPVES. Local commercial banks should act as financing intermediaries for the development of BIPVES by participating in various programs under the priority sector-lending.

- Manufacturers and installers should focus on the dissemination of reliable, locally affordable and locally acceptable BIPVES along with good after sales service of the systems installed.

- Government should initiate various policies and programs to encourage the users of BIPVES by tax exemption scheme, loan granting scheme, house tax reduction scheme etc.

- Make planners aware that while national grid power is the best power, power from BIPVES is better than no power.

- Establish marketing for BIPVES devices as the manufacturers market TVs, consumer electronics, computers and cosmetics.

- Introduce innovative taxing mechanisms for the use of polluting

- fossil fuels to channel funds for subsidy and other promotional activities of RE sources. Make transparent the flow and use of funds from such taxes.

\section{REFERENCES}

[1] Water and Energy Commission Secretariat, Government of Nepal (June 2006), Energy Synopsis Report.

[2] Nepal Electricity Authority (August 2008), Fiscal Year 2007/2008 - A Year in Review.

[3] Shrestha, J. N. et. al. (2006) Solar Radiation in Nepal :Its Implications in Telecommunication Services, Proceedings of First National Conference in Renewable Energy Technology for Rural Development, Center for Energy Studies, Institute of Engineering, T.U., 12-14 October, 2006.

[4] Ministry of Finance,(July 2008), FY 2007/2008, Economic Survey

[5] Government of Nepal, National Planning Commission, (2003), Tenth Five -Year Plan 2002-2007

[6] Water and Energy Commission Secretariat, Singh Darbar (1998), Energy Synopsis Report-Nepal, 1994/95

[7] CADEC, AEPC/ESAP (April 2008), Status of Solar Photovoltaic Sector in Nepal 2006

[8] Government of Nepal, Ministry of Environment, Science and Technology, Alternative Promotion Center (September, 2006), Subsidy for Renewable (Rural) Energy, 2006. 